\title{
Chloromethane formation and degradation in the fern phyllosphere
}

\author{
Nicole Jaeger ${ }^{\mathrm{a}, *}$, Ludovic Besaury ${ }^{\mathrm{b}, \mathrm{c}, \mathrm{g}}$, Amelie Ninja Röhling ${ }^{\mathrm{a}}$, Fabien Koch ${ }^{\mathrm{a}}$, Anne-Marie Delort ${ }^{\mathrm{b}}$, \\ Cyrielle Gasc ${ }^{\mathrm{d}}$, Markus Greule ${ }^{\mathrm{a}}$, Steffen Kolb ${ }^{\mathrm{e}}$, Thierry Nadalig ${ }^{\mathrm{c}}$, Pierre Peyret ${ }^{\mathrm{d}}$, Stéphane Vuilleumier ${ }^{\mathrm{c}}$, \\ Pierre Amato ${ }^{\mathrm{b}}$, Françoise Bringel ${ }^{\mathrm{c}}$, Frank Keppler ${ }^{\mathrm{a}, \mathrm{f}, *}$ \\ a Institute of Earth Sciences, Heidelberg University, Im Neuenheimer Feld 236, Heidelberg, Germany \\ b Institut de Chimie de Clermont-Ferrand (ICCF), UMR6096 CNRS-UCA-Sigma, Clermont-Ferrand, France \\ ' Université de Strasbourg, CNRS, GMGM UMR 7156, Department of Microbiology, Genomics and the Environment, Strasbourg, France \\ ' Université Clermont Auvergne, INRA, MEDIS, Clermont-Ferrand, France \\ e Microbial Biogeochemistry, Research Area Landscape Functioning, Leibniz Centre for Agricultural Landscape Research (ZALF), Müncheberg, Germany \\ ${ }^{\mathrm{f}}$ Heidelberg Center for the Environment HCE, Heidelberg University, Heidelberg, Germany \\ ${ }^{g}$ UMR FARE, Université de Reims Champagne Ardenne, INRA, Reims, France
}

\section{H I G H L I G H T S}

- Ferns both produce and degrade atmospheric $\mathrm{CH}_{3} \mathrm{Cl}$ with large individual variations.

- Ferns degrade $\mathrm{CH}_{3} \mathrm{Cl}$ at rates ranging from 0.3 to $17 \mu \mathrm{g} \cdot \mathrm{g}_{\text {(dry weight) }}^{-1} \mathrm{day}^{-1}$.

- $\mathrm{CH}_{3} \mathrm{Cl}$ degradation was correlated to a large $\varepsilon_{\mathrm{C}}$ and almost no $\varepsilon_{\mathrm{H}}$ isotope effect.

- Involvement of the bacterial $\mathrm{cmu}$ pathway in $\mathrm{CH}_{3} \mathrm{Cl}$ degradation was not detected.

- Still unknown $\mathrm{CH}_{3} \mathrm{Cl}$ biodegradation processes in plants contribute to the $\mathrm{CH}_{3} \mathrm{Cl}$ cycle.

\section{A R T I C L E I N F O}

\section{Article history:}

Received 27 September 2017

Received in revised form 25 March 2018

Accepted 25 March 2018

Available online 18 April 2018

Editor: P. Kassomenos

\section{Keywords:}

Biodegradation

Chloromethane

Isotope fractionation

Ferns

Phyllosphere

Methylotrophic bacteria
G R A P H I C A L A B S T R A C T

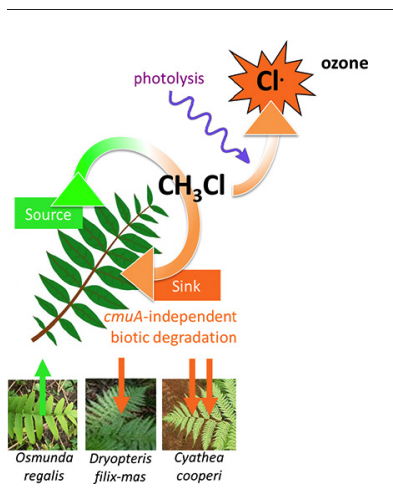

\footnotetext{
* Corresponding authors at: Institute of Earth Sciences, Heidelberg University, Im Neuenheimer Feld 234-236, Heidelberg, Germany.

E-mail addresses: nicole8jaeger@gmail.com, (N. Jaeger), frank.keppler@geow.uni-heidelberg.de. (F. Keppler).
} 
pathway "cmu" in the microbial phyllosphere of the investigated ferns. Our study suggests that still unknown $\mathrm{CH}_{3} \mathrm{Cl}$ biodegradation processes on plants play an important role in global cycling of atmospheric $\mathrm{CH}_{3} \mathrm{Cl}$.

(c) 2018 Elsevier B.V. All rights reserved.

\section{Introduction}

Since the Montreal Protocol came into force in 1987, anthropogenic emissions of ozone-depleting substances have been strongly reduced, and the relative proportion of halocarbon emissions from natural sources has increased (Carpenter and Reimann, 2014). Chloromethane $\left(\mathrm{CH}_{3} \mathrm{Cl}\right.$, also named methyl chloride) is the most abundant chlorinated organic compound in the atmosphere, with an estimated global $\mathrm{CH}_{3} \mathrm{Cl}$ emission rate of 4 to $5 \mathrm{Tg}\left(1 \mathrm{Tg}=10^{12} \mathrm{~g}\right.$ ) per year (Xiao et al., 2010; Keppler et al., 2005). This estimate is based on its mean mixing ratio of $540 \pm 5$ parts per trillion by volume (pptv) and atmospheric lifetime of $1.0-1.2$ years.

$\mathrm{CH}_{3} \mathrm{Cl}$ is predominantly emitted from natural sources, including tropical and senescent plants (Yokouchi et al., 2002; Hamilton et al., 2003; Yokouchi et al., 2015; Blei et al., 2010), grasslands (Rhew and Abel, 2007; Teh et al., 2008; Rhew, 2011), peatlands (Dimmer et al., 2001), salt marshes (Rhew et al., 2000; Valtanen et al., 2009), aerated and flooded soil (Keppler et al., 2000; Redeker et al., 2000), woodrotting fungi (Harper, 1985) and oceans (Moore et al., 1996), but also from anthropogenic sources, like biomass burning or industrial emissions (Carpenter and Reimann, 2014). However industrial sources have been considered minor (Keene et al. 1999), although very recently it has been reported that $\mathrm{CH}_{3} \mathrm{Cl}$ emission from industrial sources particularly from China might be much higher than previously assumed ( $\mathrm{Li}$ et al., 2016). Within natural sources in particular, ferns are strong $\mathrm{CH}_{3} \mathrm{Cl}$ emitters under diverse climate conditions, including tropical, subtropical, temperate and cool-temperate zones (Yokouchi et al., 2002 , 2015), with $\mathrm{CH}_{3} \mathrm{Cl}$ emission rates up to a few $\mu \mathrm{g} \mathrm{g} \mathrm{dw}^{-1} \mathrm{~h}^{-1}$. The best characterized biogenic $\mathrm{CH}_{3} \mathrm{Cl}$ production is an enzymatic mechanism. A protein encoded by the gene HOL (harmless to the ozone layer) catalyzes the $S$ adenosyl L methionine (SAM)-dependent methylation of chloride $\left(\mathrm{Cl}^{-}\right.$) (Wuosmaa and Hager, 1990; Ni and Hager, 1999; Rhew et al., 2003). A high HOL-type enzyme activity was detected in the highly $\mathrm{CH}_{3} \mathrm{Cl}$-forming fern $\mathrm{C}$. lepifera (Yokouchi et al., 2002; Itoh et al., 2009). Nonetheless, the factors controlling this rate are poorly understood. Furthermore, abiotic production of $\mathrm{CH}_{3} \mathrm{Cl}$ in plant material has also been reported, with carbon originating from pectin and lignin methoxyl groups (Hamilton et al., 2003; Wishkerman et al., 2008; Sailaukhanuly et al., 2014). This ubiquitous process is active in terrestrial ecosystems at ambient temperatures, but is much more efficient at higher temperatures, such as during biomass burning (Hamilton et al., 2003; McRoberts et al., 2015).

The dominant sink for atmospheric $\mathrm{CH}_{3} \mathrm{Cl}$ results from the reaction with photochemically-produced $\mathrm{OH}$ radicals, currently estimated at about $2.8 \mathrm{Tg}_{\text {year }}{ }^{-1}$ (Carpenter and Reimann, 2014). Microbial $\mathrm{CH}_{3} \mathrm{Cl}$ degradation in soils may be a relevant additional global sink (McAnulla et al., 2001b; Harper and Hamilton, 2003; Miller et al., 2004; Jaeger et al., 2018), but its impact on the global $\mathrm{CH}_{3} \mathrm{Cl}$ budget is uncertain. The microbial $\mathrm{CH}_{3} \mathrm{Cl}$ soil sink strength has been estimated to range from 0.1 to $1.6 \mathrm{Tg}_{\text {year }}{ }^{-1}$ (Carpenter and Reimann, 2014; Harper and Hamilton, 2003; Keppler et al., 2005). Different types of methylotrophic bacteria capable of utilizing $\mathrm{CH}_{3} \mathrm{Cl}$ as the only carbon and energy source have been isolated from various environments, including soils (Doronina et al., 1996; McAnulla et al., 2001b; Miller et al., 2004), sludge (Hartmans et al., 1986; Traunecker et al., 1991; Freedman et al., 2004.), seawater (Schäfer et al., 2005), and plant leaves (Nadalig et al., 2011). Consumption potentials of $\mathrm{CH}_{3} \mathrm{Cl}$ in soils (Miller et al., 2004; Jaeger et al., 2018) and the plant environment of the phyllosphere (above-ground portions of plants) (Saito et al., 2013) have been investigated. When both foliar production and consumption of $\mathrm{CH}_{3} \mathrm{Cl}$ were evaluated, large net emissions of $\mathrm{CH}_{3} \mathrm{Cl}$ were found (Saito et al., 2013). Indeed, plants colonized with methylotrophic microorganisms able to consume volatile one-carbon compounds exhibit lower emission rates (Ababda-Nkpwatt et al., 2006). Bacteria able to degrade $\mathrm{CH}_{3} \mathrm{Cl}$ have been isolated from plant leaves and may utilize the $\mathrm{cmu}$ chloromethane utilization pathway (Nadalig et al., 2014). The only $\mathrm{CH}_{3} \mathrm{Cl}$ degradation pathway characterized in detail, was mainly studied in Methylobacterium extorquens CM4, an aerobic methylotrophic strain able to use $\mathrm{CH}_{3} \mathrm{Cl}$ as the sole source of carbon and energy (Chaignaud et al., 2017; Roselli et al., 2013; Vanelli et al., 1999). In this pathway, the $\mathrm{CH}_{3} \mathrm{Cl}$ dehalogenase includes a corrinoid methyltransferase $(\mathrm{CmuA})$ and a tetrahydrofolate-dependent methyltransferase $(\mathrm{CmuB})$ (Studer et al., 2001, 1999). Bacterial isolates known to degrade $\mathrm{CH}_{3} \mathrm{Cl}$ by the $\mathrm{cmu}$ pathway are taxonomically diverse and include organisms affiliated with 7 genera so far (Acetobacterium, Aminobacter, Hyphomicrobium, Leisingera, Methylobacterium, Pseudomonas and Roseovarius) (Nadalig et al., 2011). Nevertheless, other as yet uncharacterized pathways for $\mathrm{CH}_{3} \mathrm{Cl}$ degradation exist, such as in Leisingera methylohalidivorans MB2, as demonstrated using stable isotope fractionation of carbon and hydrogen (Nadalig et al., 2014).

Two-dimensional stable isotope approach of hydrogen and carbon can be used to better understand the processes of $\mathrm{CH}_{3} \mathrm{Cl}$ biodegradation and formation. Combined with $\mathrm{CH}_{3} \mathrm{Cl}$ flux measurements, it can help constrain the strengths of $\mathrm{CH}_{3} \mathrm{Cl}$ sinks and sources within the global $\mathrm{CH}_{3} \mathrm{Cl}$ budget (Keppler et al., 2005; Saito and Yokouchi, 2008). Isotope fractionation occurs due to enzymatic discrimination of heavier isotopes against their lighter counterparts, because of the lower energy required for reaction by the latter. In the case of chloromethane, carbon directly present in the key $\mathrm{C}-\mathrm{Cl}$ bond defines the so-called primary isotope effect, whereas hydrogen is affected by a secondary isotope effect (Elsner et al., 2005). A few studies have measured the stable isotope fractionation of carbon and hydrogen during $\mathrm{CH}_{3} \mathrm{Cl}$ biodegradation by bacterial isolates (Miller et al., 2001; Nadalig et al., 2013, 2014) or in soils under laboratory conditions (Miller et al., 2004; Jaeger et al., 2018). For plants, several studies have investigated the stable isotope signature of $\mathrm{CH}_{3} \mathrm{Cl}$ produced via biotic (Saito and Yokouchi, 2008; Harper et al., 2003) and abiotic processes (Keppler et al., 2004; Greule et al., 2012).

The main aim of this study was to investigate the $\mathrm{CH}_{3} \mathrm{Cl}$ degradation potential by ferns known to produce $\mathrm{CH}_{3} \mathrm{Cl}$ (Yokouchi et al., 2002, 2015). We determined both the production and consumption rates of $\mathrm{CH}_{3} \mathrm{Cl}$ of several abundant ferns. Using a stable isotope tracer technique, we differentiated between formation and degradation processes within the same fern, and assessed the correlation between ability for $\mathrm{CH}_{3} \mathrm{Cl}$ biodegradation and phyllospheric occurrence of bacterial taxa previously described to be associated with $\mathrm{CH}_{3} \mathrm{Cl}$ degradation.

\section{Material and methods}

\subsection{Plant material and sampling}

Plant samples were collected in the Botanical Garden of Heidelberg University. Leaf samples of Cyathea cooperi (accession number: 108562), Osmunda regalis (accession number: 004923) and Dryopteris filix-mas (accession number: 002834) were collected in May, July and September 2016, respectively. In the laboratory, fern leaves were separated in detached pinnules according to Yokouchi et al. (2015) (for $D$. filix-mas the primary and for $C$. cooperi and $O$. regalis the secondary division of a pinnate leaf of a fern). The incubation of the collected leaves started within $2 \mathrm{~h}$ after sampling. 
2.2. Stable isotope tracer-based measurements for chloromethane consumption and production rates

Fresh fern leaf samples ( $5 \mathrm{~g}$ ) were incubated in $170 \mathrm{~mL}$ gastight incubation flasks at $20^{\circ} \mathrm{C}$ and spiked with 5 parts per million by volume (ppmv) of the stable isotope ${ }^{13} \mathrm{CH}_{3} \mathrm{Cl}$ (99.7 at.\% labeled). The incubations were stopped after a maximum of $6 \mathrm{~h}$. The simultaneous measurement of ${ }^{12} \mathrm{CH}_{3} \mathrm{Cl}$ and ${ }^{13} \mathrm{CH}_{3} \mathrm{Cl}$ concentrations at different time points was used to determine gross production and uptake rates. The headspace was investigated for at least 4 time points. Therefore, $200 \mu \mathrm{L}$ sample were injected in a flow of $1 \mathrm{~mL} / \mathrm{min}$ of helium (split ratio 5:1) on a GasPro column $(60 \mathrm{~m} \times 0.32 \mathrm{~mm}$ i.d., Agilent Technologies $)$ and isothermally $\left(150^{\circ} \mathrm{C}\right)$ quantified by a Hewlett Packard HP 6890 gas chromatograph coupled to a MSD 5973 mass spectrometer (GC-MS, Agilent Technologies, Palo Alto, CA). By single ion monitoring mode the four stable isotopologues of $\mathrm{CH}_{3} \mathrm{Cl}$ were detected $\left(\mathrm{m} / \mathrm{z}=50\right.$ for ${ }^{12} \mathrm{CH}_{3}^{35} \mathrm{Cl}, \mathrm{m} / \mathrm{z}$ $=52$ for ${ }^{12} \mathrm{CH}_{3}^{37} \mathrm{Cl}, m / z=51$ for ${ }^{13} \mathrm{CH}_{3}^{35} \mathrm{Cl}, \mathrm{m} / z=53$ for $\left.{ }^{13} \mathrm{CH}_{3}^{37} \mathrm{Cl}\right)$. However, during the detection via the quadrupole mass spectrometer ion fragmentation occurs and need to be corrected in such isotope tracer studies (Rhew and Abel, 2007), since e.g. ${ }^{13} \mathrm{CH}_{2} \mathrm{Cl}^{+}$yields the same $\mathrm{m} /$ $z$ as ${ }^{12} \mathrm{CH}_{3} \mathrm{Cl}$. Therefore ${ }^{12} \mathrm{CH}_{3} \mathrm{Cl} /{ }^{13} \mathrm{CH}_{3} \mathrm{Cl}$ fragmentation ratios were determined experimentally and detected areas corrected for it. Gross production $\left({ }^{12} \mathrm{CH}_{3} \mathrm{Cl}\right)$ and uptake $\left({ }^{13} \mathrm{CH}_{3} \mathrm{Cl}\right)$ rates were calculated by the slope of a linear fit applied to the dry weight based concentration of the respective isotopologues ( $\mu \mathrm{g} \mathrm{g}-1$ ) versus time (day).

Additionally, to check for biotic degradation and to exclude abiotic production with increasing temperature, the ferns that showed net $\mathrm{CH}_{3} \mathrm{Cl}$ degradation (C. cooperi, D. filix-mas) were spiked with $10 \mathrm{ppmv}$ ${ }^{13} \mathrm{CH}_{3} \mathrm{Cl}$ and incubated at increasing temperature in $10{ }^{\circ} \mathrm{C}$ steps until net $\mathrm{CH}_{3} \mathrm{Cl}$ uptake rates decreased.

Furthermore $C$. cooperi and $D$. filix-mas samples were incubated to assess their production potential. These incubations did not include the ${ }^{13} \mathrm{CH}_{3} \mathrm{Cl}$ stable isotope tracer described in the section before, thereby avoiding the possibility of reversing an enzyme mediated production reaction (i.e., making a source into a sink).

\subsection{Determination of chloromethane consumption rates}

C. cooperi samples (20 g) were incubated in triplicate in gastight incubation flasks $(800 \mathrm{~mL})$ at different temperatures $\left(5,20,30{ }^{\circ} \mathrm{C}\right)$. Samples were first equilibrated to the respective incubation temperature, before headspace was spiked with 10 and 100 ppmv $\mathrm{CH}_{3} \mathrm{Cl}$ (99.8\%). The headspace was sampled at least at 4 time points until the remaining fraction was $<50 \%$. Chloromethane was directly quantified by GC-MS and net uptake rates were calculated by a linear fit applied to the dry weight based concentration ( $\mu \mathrm{g} \mathrm{g}_{\mathrm{dw}}^{-1}$ ) versus time (day). The resulting slope represents $-k_{\text {net }}$. For IRMS measurements, at each time point, $25 \mathrm{~mL}$ of the headspace was stored in $12 \mathrm{~mL}$ Exetainer ${ }^{\circledR}$ (Labco Limited, Lampeter, UK) until analyses. For the bacterial investigations, plant leaf samples were collected and stored at $-18{ }^{\circ} \mathrm{C}$, both at the beginning and at the end of the incubation experiments (maximal $6 \mathrm{~h}$ ).

\subsection{Determination of chloromethane production rates}

O. regalis samples $(5 \mathrm{~g})$ were incubated in triplicate in gastight incubation flasks $(170 \mathrm{~mL})$ at different temperatures $\left(5,20,30,40{ }^{\circ} \mathrm{C}\right)$. The headspace was sampled at least at 4 time points and $\mathrm{CH}_{3} \mathrm{Cl}$ was directly quantified by GC-MS. Net production rates were calculated by the slope of a linear fit applied to the dry weight based concentration ( $\mu \mathrm{g} \mathrm{g}_{\mathrm{dw}}^{-1}$ ) versus time (day). Additionally, at the end of the incubation we sampled $25 \mathrm{~mL}$ of the headspace for IRMS measurements, stored in $12 \mathrm{~mL}$ Exetainer ${ }^{\circledR}$ until analyses. At both the beginning and the end of the incubation experiments (maximal $6 \mathrm{~h}$ ), we collected 0 . regalis samples for the bacterial investigations and stored them at $-18^{\circ} \mathrm{C}$.

\subsection{Stable isotope analysis of chloromethane}

Stable hydrogen and carbon isotope ratios of $\mathrm{CH}_{3} \mathrm{Cl}$ were measured by an in-house built cryogenic pre-concentration unit coupled to a Hewlett Packard HP 6890 gas chromatograph (Agilent Technologies, Palo Alto, CA) and an isotope ratio mass spectrometer (IRMS) (Isoprime, Manchester, UK) according to Nadalig et al. (2013) and Jaeger et al. (2018). The conventional delta notation, expressing the isotopic composition of the sample relative to that of V-SMOW standard (Vienna Standard Mean Ocean Water) for hydrogen $\left(\delta^{2} \mathrm{H}_{V-S M O w}\right)$ and V-PDB standard (Vienna Pee Dee Belemnite) for carbon $\left(\delta^{13} C_{V-P D B}\right)$ on per mil basis is used. The isotope fractionation factor $\alpha$ and the isotope enrichment factor $\varepsilon$ are derived from the slope of the Rayleigh plot according to Elsner et al. (2005) and Elsner (2010). Negative $\varepsilon$ indicates that the remaining $\mathrm{CH}_{3} \mathrm{Cl}$ is enriched in the heavier isotope and corresponds to an $\alpha<1$, meaning that the heavier $\left[{ }^{13} \mathrm{C}\right]-\mathrm{CH}_{3} \mathrm{Cl}$ reacted more slowly by this factor than the lighter $\left[{ }^{12} \mathrm{C}\right]-\mathrm{CH}_{3} \mathrm{Cl}$ during incubation.

\subsection{Determination of stable isotope values of plant methoxyl groups}

Stable hydrogen and carbon isotope values of plant methoxyl groups $\left(\mathrm{OCH}_{3}\right)$ can be measured without isotope fractionation as iodomethane $\left(\mathrm{CH}_{3} \mathrm{I}\right)$ upon treatment of plant matter with hydriodic acid. Stable isotope values of methoxyl groups of the fern samples were measured according to the procedure described by Greule et al. (2008, 2009). Briefly, $250 \mu \mathrm{L}$ hydriodic acid (55-58\%; Fluka, Buchs, Switzerland) were added to $40 \mathrm{mg}$ of dried and milled 0 . regalis samples and heated at $130{ }^{\circ} \mathrm{C}$ for $30 \mathrm{~min}$. After equilibration to room temperature, the stable isotope values of produced $\mathrm{CH}_{3} \mathrm{I}$ were measured by Hewlett Packard HP $6890 \mathrm{~N}$ gas chromatograph (Agilent Technologies, Palo Alto, CA) coupled to Delta ${ }^{\text {PLUS }} \mathrm{XL}$ isotope ratio mass spectrometer (ThermoQuest Finnigan, Bremen, Germany).

\subsection{DNA extraction from fern phyllosphere}

To harvest the microbial cells associated with the plant, leaf samples ( 5 to $10 \mathrm{~g}$ ) were immersed in sterile $50 \mathrm{~mL}$ of potassium phosphate buffer $(0.1 \mathrm{M}, \mathrm{pH} 8.0)$ in a $100 \mathrm{~mL}$ sterile Schott-bottle plunged into an ultrasonication bath for $5 \mathrm{~min}$. The bottles were then shaken manually and vortexed twice. The microbial cells of the supernatant were collected by filtration on a GNWP $0.22 \mu \mathrm{m}$ filter (Millipore, France) and stored at $-20^{\circ} \mathrm{C}$. Microbial DNA was extracted directly from the filters using MoBio's Power Water DNA Isolation kit according to the manufacturer's protocol. DNA was quantified using the ND-1000 spectrophotometer (NanoDrop Technologies Inc., Wilmington, USA). DNA quality was controlled after electrophoresis on a $0.8 \%(\mathrm{w} / \mathrm{v})$ agarose gel made with Tris acetate EDTA buffer (TAE $1 \times$ buffer) and stored at $-20^{\circ} \mathrm{C}$.

\subsection{PCR amplification, and sample pooling}

DNA was used as template for 16S rRNA gene amplification in PCR reactions with universal primers 799F and 1193r targeting the V5, V6 and $\mathrm{V} 7$ regions of the gene and barcoded for multiplexed sequencing (Table SM1) as described (Bulgarelli et al., 2015). Each $50 \mu \mathrm{L}$ PCR reaction contained $1 \mathrm{ng}$ of DNA, $20 \mathrm{mM}$ Tris $\mathrm{HCl}$ (pH 8.4), $50 \mathrm{mM} \mathrm{KCl}$, $3 \mathrm{mM} \mathrm{MgCl}_{2}, 200 \mathrm{mM}$ dNTP, $200 \mathrm{nM}$ of each reverse and forward primer and 0.8 units of Taq DNA Polymerase (MP Biomedicals). The targeted amplicons sizing 394 bp were isolated on 2\% agarose gel using QIAquick gel extraction kit (Qiagen) following the manufacturer's instructions, and quantified using Qubit (ThermoFisher, France) and pooled at equimolar concentrations. Sequencing was done at a final library concentration of $5 \mathrm{pM}$ and incorporation of the control library PhiX at 15\% (V/V). This control shotgun "library" was built from the genome of the PhiX174 phage. The resulting pool was sequenced on Illumina Miseq $2 * 250$ bp (GenoScreen, France). 
DNA was also used to amply an inter-domain region of the proteinencoding gene cmuA of $422 \mathrm{bp}$. The $50 \mu \mathrm{L}$ PCR reaction volume contained $1 \times$ buffer including $\mathrm{MgCl}_{2}, 0.8 \mathrm{mM}$ dNTPs $(0.2 \mathrm{mM}$ each dNTP), $1121 \mathrm{nM}$ of primer cmuAf422 and $258 \mathrm{nM}$ of primer cmuAr422 (Table SM 1, 2 U Taq DNA polymerase (Platinum Taq, Invitrogen Corporation, Carlsbad, USA), template DNA (1-10 ng). PCR program had an initial step at $95^{\circ} \mathrm{C}$ for $10 \mathrm{~min}$, followed by 30 cycles of $15 \mathrm{~s}$ at $94^{\circ} \mathrm{C}$ (denaturation) and $56{ }^{\circ} \mathrm{C}$ for $60 \mathrm{~s}$ (hybridization/elongation), and a final extension step at $72{ }^{\circ} \mathrm{C}$ for $5 \mathrm{~min}$.

\subsection{Bioinformatics analysis}

Illumina reads $(2,805,832$ sequences with an average contig length of $411 \mathrm{bp}$ ) were analyzed using Mothur software package (v 1.39.1; Schloss et al., 2009) with the Miseq standard operating procedure (http://www.mothur.org/wiki/MiSeqSOP). Briefly, mate pairs were assembled, subjected to quality filtering (phred quality score $Q \geq 28$ ) and aligned and classified against SILVA SSURef database v128 (Quast et al., 2012). Unique sequences were screened and further de-noised based on pre-clustered command for up to 2 differences between sequences. Putative chimera sequences were removed using UCHIME (Edgar et al., 2011). Sequences assigned to plastid-chloroplast-mitochondria taxa were removed (16S rRNA amplification using primer 799F only minimized amplification of the plant host chloroplast DNA and the mtDNA sequences; Bringel and Couée, 2015). Remaining sequences were clustered into operational taxonomic units (OTUs) at an identity level of $97 \%$.

\subsection{Ecological and statistical analysis}

Total richness and alpha diversity indices were calculated on datasets rarefied to similar sequence number (613 sequences) using Mothur software (Schloss et al., 2009). Rarefaction curves were plotted and diversity indices calculated using the Mothur "summary single" command. For each tested $\mathrm{CH}_{3} \mathrm{Cl}$-incubation condition, OTUs enrichment factors were calculated as their mean relative abundance of triplicates in sequence datasets at the end-point of the incubation experiments compared to corresponding "time zero". Multivariate and univariate statistical analyses and graphical representations were performed using SigmaPlot 13, PAST v3 (Hammer et al., 2001), and R version 3.3.1.

\subsection{Capture sequencing of cmuA gene}

A set of nineteen 80 -mer degenerate non-overlapping probes (Table SM3) covering the complete cmuA gene was designed using KASpOD software (Parisot et al., 2012). Adaptor sequences were added to the ends of the probes to enable their amplification by PCR, resulting in "ATCGCACCAGCGTGT-N ${ }_{80}$-CACTGCGGCTCCTCA" sequences, with $\mathrm{N}_{80}$ representing the $c m u A$ gene-specific capture probe. Biotinylated RNA probes were then synthesized as described by Ribière et al. (2016). In brief, adaptors containing the T7 promoter were added to the capture probes through ligation-mediated PCR, and the final biotinylated RNA probes were obtained after in vitro transcription and purification. A NGS library was constructed from an equimolar pool of DNA extracted from the microbial communities of leaves of all fern $C$. cooperi samples using Nextera kit (Illumina), according to the manufacturer's instructions. Hybridization capture was then conducted as described in Ribière et al. (2016). Briefly, 500 ng of biotinylated RNA probes and $500 \mathrm{ng}$ of denatured Illumina library were incubated at $65^{\circ} \mathrm{C}$ for $24 \mathrm{~h}$. The probe/target heteroduplexes were captured using streptavidincoated paramagnetic beads, and the captured fragments were eluted with $\mathrm{NaOH}$. To increase the enrichment efficiency, a second round of hybridization capture was performed using the first-round capture products. Enriched DNA was then sequenced using $1 / 8$ of an Illumina MiSeq $2 \times 250$ bp run. Sequence data files (510,036 paired-end reads total) were filtered for quality using FastQC (Andrews, 2010), trimmed using Prinseq-Lite (Schmieder and Edwards, 2011), de novo assembled using SPAdes (Bankevich et al., 2012), and mapped using Bowtie2 (Langmead and Salzberg, 2012) to a pre-built cmuA database containing $122 \mathrm{cmuA}$ nucleotide sequences of lab-isolated strain to non-cultivated environmental taxa. The sorted reads were then blasted on a local server on that same cmuA database in order to reveal the diversity of the plant sample retrieved cmuA sequences.

\subsection{Nucleotide sequence accession numbers}

Nucleotide sequences generated during this study were deposited in GenBank under Bioproject accession no. PRJNA393101.

\section{Results and discussion}

\subsection{Measurements of chloromethane production and degradation}

We first monitored potential $\mathrm{CH}_{3} \mathrm{Cl}$ emissions from 3 representative fern species Cyathea cooperi, Osmunda regalis and Dryopteris filix-mas collected from the Botanical Garden of Heidelberg University incubated at $20{ }^{\circ} \mathrm{C}$ in the laboratory. While $\mathrm{O}$. regalis showed clear $\mathrm{CH}_{3} \mathrm{Cl}$ production, the other two ferns did not show measurable $\mathrm{CH}_{3} \mathrm{Cl}$ production (Table 1). Based on the detection limit of the applied analytical system, $\mathrm{CH}_{3} \mathrm{Cl}$ production rates for $C$. cooperi and $D$. filix-mas were below 0.05 $\mu \mathrm{g} \mathrm{g} \mathrm{dw}^{-1} \mathrm{day}^{-1}$. The lack of production in C. cooperi observed in our study differs from previously studied Cyathea species (Table 1). Production rates of 0 . regalis were in the range of 0.6 to $128 \mu \mathrm{g} \mathrm{g}_{\mathrm{dw}}^{-1} \mathrm{day}^{-1}$, with a high variability of rates from different $O$. regalis plant individuals and sampling times, which may due to different plant vitality, as also noted previously (Yokouchi et al., 2007). Measured emission rates were in agreement with previous results on other Osmunda species, with observed rates varying from 2 to $144 \mu \mathrm{g} \mathrm{g} \mathrm{dw}^{-1}$ day $^{-1}$ (Yokouchi et al., 2007, 2015; Table 1).

Production and consumption processes might be simultaneously active in plants. A stable carbon isotope tracer technique was used to differentiate a possible overlay of uptake and production processes (Rhew et al., 2003; Saito et al., 2013). We found contrasting behavior between ferns with different roles as $\mathrm{CH}_{3} \mathrm{Cl}$ source and sink. O. regalis showed a strong natural ${ }^{12} \mathrm{CH}_{3} \mathrm{Cl}$ production, while the supplemented ${ }^{13} \mathrm{CH}_{3} \mathrm{Cl}$ remained constant during the incubation (when 5 ppmv ${ }^{13} \mathrm{CH}_{3} \mathrm{Cl}$ was supplemented), suggesting that no measurable degradation of $\mathrm{CH}_{3} \mathrm{Cl}$ occurred during incubation (Fig. 1B). Here it should be noted, that due to the strong production of $O$. regalis, uptake is possibly underestimated (Rhew, 2011).

In contrast, $C$. cooperi and $D$. filix-mas investigated in our study consumed the supplemented ${ }^{13} \mathrm{CH}_{3} \mathrm{Cl}$ (5 ppmv), while no ${ }^{12} \mathrm{CH}_{3} \mathrm{Cl}$ production was detectable (Fig. $1 \mathrm{~A}, \mathrm{C}$ ). At $20{ }^{\circ} \mathrm{C}$ C. cooperi showed degradation rates from 2.1 to $17 \mu \mathrm{g} \mathrm{g} \mathrm{dw}^{-1} \mathrm{day}^{-1}$, which were higher

Table 1

$\mathrm{CH}_{3} \mathrm{Cl}$ sinks and sources associated with fern leaves. Comparison of rates determined by stable isotope tracer technique in this work with the literature.

\begin{tabular}{|c|c|c|c|}
\hline \multirow[t]{2}{*}{ Fern plants } & \multicolumn{2}{|c|}{$\begin{array}{l}\mathrm{CH}_{3} \mathrm{Cl} \text { flux rate } \\
\left(\mu \mathrm{g} \mathrm{g}_{\mathrm{dw}}^{-1} \mathrm{day}^{-1}\right) \\
\end{array}$} & \multirow[t]{2}{*}{ Reference } \\
\hline & Degradation & Production & \\
\hline C. cooperi & $2.1-17^{\mathrm{a}}$ & $<0.05$ & This work \\
\hline C. lepifera & n.d. & $1.7-88.3$ & $\begin{array}{l}\text { Yokouchi et al., 2002, } 2007 \\
\text { Saito and Yokouchi, 2006, } 2008\end{array}$ \\
\hline C. podophylla & n.d. & $57.6 \pm 14.4$ & $\begin{array}{l}\text { Yokouchi et al., } 2007 \\
\text { Saito and Yokouchi, 2006, } 2008\end{array}$ \\
\hline D. filix-mas & $0.3-0.9^{\mathrm{a}}$ & $<0.05$ & This work \\
\hline O. banksiifolia & n.d. & 26 & Yokouchi et al., 2007 \\
\hline O. japonica & n.d. & $2-144$ & Yokouchi et al., 2015 \\
\hline 0. regalis & $<0.2$ & $0.6-128$ & This work \\
\hline
\end{tabular}

n.d. not determined.

a Spiked with 5 ppmv $\mathrm{CH} 3 \mathrm{Cl}$ at $20^{\circ} \mathrm{C}$. 
A

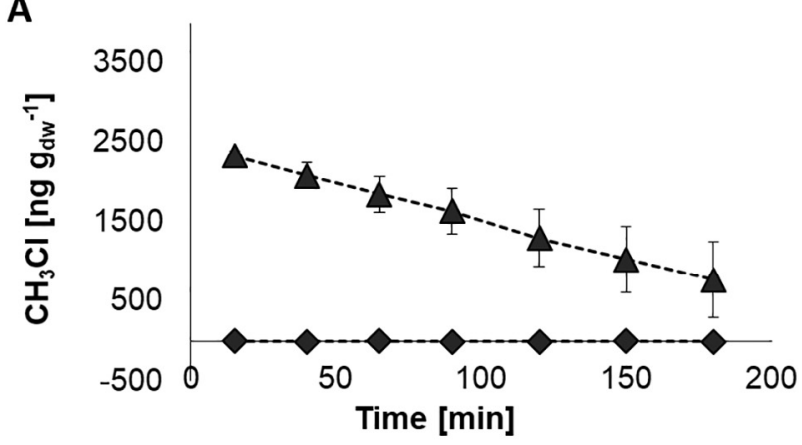

B

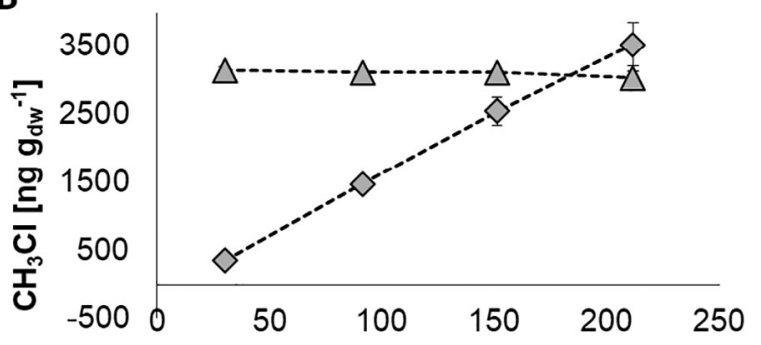

C

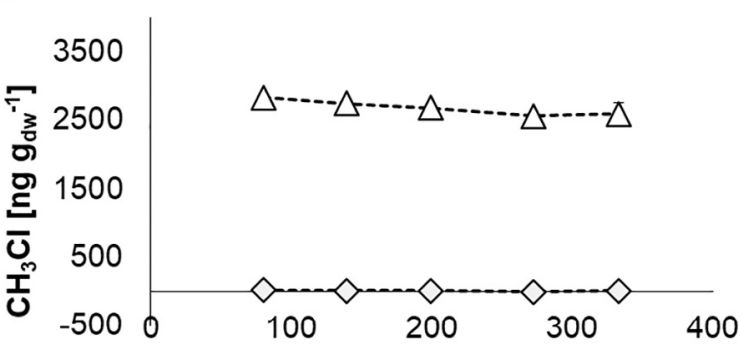

Time [min]

Fig. 1. Stable isotope tracer experiments showing ${ }^{13} \mathrm{CH}_{3} \mathrm{Cl}$ (triangles) and ${ }^{12} \mathrm{CH}_{3} \mathrm{Cl}$ (rhombus) concentrations during incubation of $C$. cooperi (black, $n=3)(A), O$. regalis (grey, $\mathrm{n}=3$ ) (B) and $D$. filix-mas (white, $\mathrm{n}=2$ ) (C) plant samples, spiked with $5 \mathrm{ppmv}$ of ${ }^{13} \mathrm{CH}_{3} \mathrm{Cl}$ at $20{ }^{\circ} \mathrm{C}$. Error bars indicate standard deviation of the mean of three independent experiments. Some error bars lie within the symbol.

compared to rates measured for $D$. filix-mas of about 0.3 to $0.9 \mu \mathrm{g} \mathrm{g}_{\mathrm{dw}}^{-1} \mathrm{day}^{-1}$. However, measured $\mathrm{CH}_{3} \mathrm{Cl}$ consumption rates were much higher than that of tropical trees $\left(0.1 \pm 0.07 \mu \mathrm{g} \mathrm{g} \mathrm{dw}^{-1}\right.$ day $^{-1}$ : Saito et al., 2013). Furthermore, both degrading ferns showed increasing uptake rates with increasing temperature up to $40{ }^{\circ} \mathrm{C}$, which then strongly decreased at $50{ }^{\circ} \mathrm{C}$ (Fig. 2). As noted previously, this indicates that $\mathrm{CH}_{3} \mathrm{Cl}$ degradation originates mainly from biotic processes such as bacterial degradation (Farhan ul Haque et al., 2017). However, plant related enzymatic processes might be also involved in $\mathrm{CH}_{3} \mathrm{Cl}$ consumption.

\subsection{Biogenic chloromethane production and its stable isotopic signature}

As expected, $\mathrm{CH}_{3} \mathrm{Cl}$ production rates by 0 . regalis were dependent on temperature: lowest at $5{ }^{\circ} \mathrm{C}$, highest at 20 or $30{ }^{\circ} \mathrm{C}$ (Fig. 3) and substantially decreased at $40{ }^{\circ} \mathrm{C}$, which altogether indicates a predominately biotic process of $\mathrm{CH}_{3} \mathrm{Cl}$ production by 0 . regalis. Wuosmaa and Hager (1990) discovered a methyl chloride transferase catalyzing the formation of $\mathrm{CH}_{3} \mathrm{Cl}$ via reaction of $S$ adenosyl $\mathrm{L}$ methionine (SAM) with chloride ion for the white rot fungus Phellinus pomaceus. A similar process of enzymatic $\mathrm{CH}_{3} \mathrm{Cl}$ production was reported in Arabidopsis thaliana (Rhew et al., 2003), and suggested to be widespread among vascular plants.

Stable carbon isotope signature $\left(\delta^{13} \mathrm{C}\right.$ value $)$ of $\mathrm{CH}_{3} \mathrm{Cl}$ produced by O. regalis at $20^{\circ} \mathrm{C}$ was $-97 \pm 8 \%$, a value more negative than the reported mean $\delta^{13} \mathrm{C}$ values of ferns including Angiopteris lygodiifolia, C. lepifera, C. podophylla ( $-61.9 \pm 9.7 \%$; Saito and Yokouchi, 2008), Angiopteris evecta and C. smithii (around -71\%; Harper et al., 2003). In these studies, although biodegradation processes were not assessed, they may impact overall $\delta^{13} \mathrm{C}$ values of $\mathrm{CH}_{3} \mathrm{Cl}$ (see discussion below for the other two ferns). The stable hydrogen isotope signature $\left(\delta^{2} \mathrm{H}\right.$ value) of emitted $\mathrm{CH}_{3} \mathrm{Cl}$ by 0 . regalis at $20{ }^{\circ} \mathrm{C}$ was $-202 \pm 10 \%$. As far as we know, this is the first $\delta^{2} \mathrm{H}$ value of $\mathrm{CH}_{3} \mathrm{Cl}$ reported for biogenic emissions from a living fern, which is in the range of what has been reported for abiotic $\mathrm{CH}_{3} \mathrm{Cl}$ release from other dried plants ( -155 to $-290 \%$ ) when heated at temperatures between 30 and $300{ }^{\circ} \mathrm{C}$ (Greule et al., 2012). In their study, $\delta^{2} \mathrm{H}$ values of thermally emitted $\mathrm{CH}_{3} \mathrm{Cl}$ were not affected by varying temperatures but correlated with $\delta^{2} \mathrm{H}$ values of the plant source water (meteoric water) and plant methoxyl groups $\left(\mathrm{OCH}_{3}\right)$ (Greule et al., 2012). Under elevated temperatures such as during biomass burning, the plant structural components lignin and pectin (both containing methoxyl groups) can be chlorinated under different environmental conditions, leading to the release of substantial amounts of $\mathrm{CH}_{3} \mathrm{Cl}$ (Hamilton et al., 2003; Keppler et al., 2004; McRoberts et al., 2015). However, at low ambient temperatures of $20^{\circ} \mathrm{C}$ the abiotic $\mathrm{CH}_{3} \mathrm{Cl}$ release from air-dried pinnules of 0 . regalis was found to be below the detection limit of the analytical system. Moreover, the measured $\delta^{2} \mathrm{H}$ value of methoxyl groups from 0 . regalis of $-259 \pm 0.2 \%$ owas in the range published by Greule et al. (2012) for other plants ( -200 to $-296 \%$ ). Carboxyl groups in pectin and lignin are esterified by the enzyme pectin $O$ methyltransferase (PMT) using $S$ adenosylmethionine (SAM) as methyl donor (Weilacher et al., 1996). We thus considered that the methyl groups provided for chloride methylation during biogenic and abiotic formation both originate

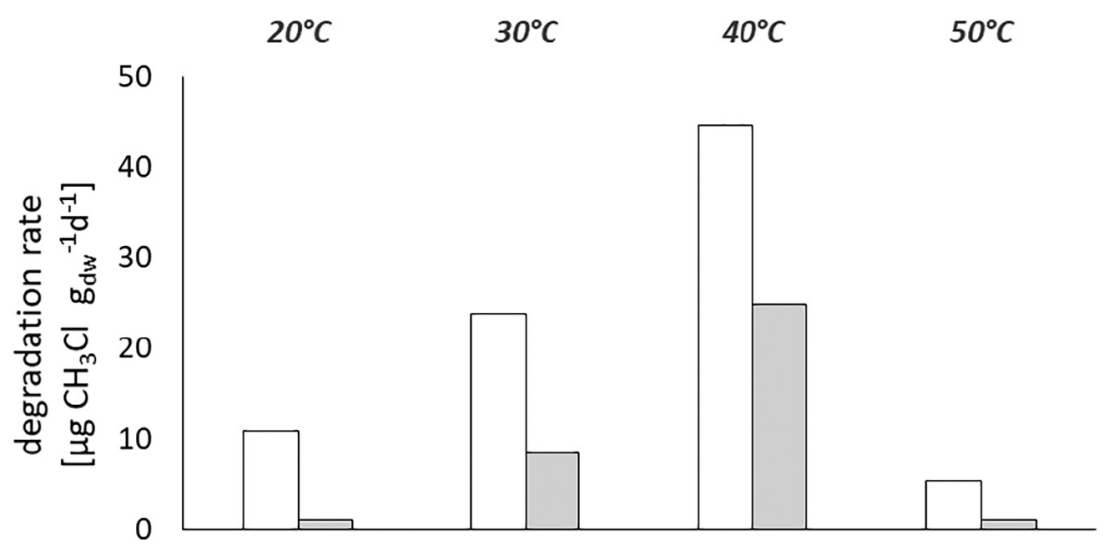

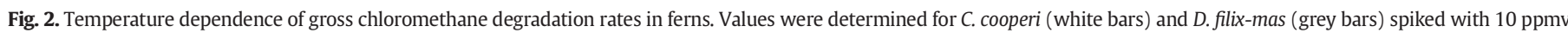
${ }^{13} \mathrm{CH}_{3} \mathrm{Cl}$ at $20{ }^{\circ} \mathrm{C}, 30{ }^{\circ} \mathrm{C}, 40{ }^{\circ} \mathrm{C}$ and $50{ }^{\circ} \mathrm{C} ;\left(\mathrm{n}=1 ; \mathrm{R}^{2}=0.98\right.$ for C. cooperi $\left(20-40{ }^{\circ} \mathrm{C}\right) ; \mathrm{R}^{2}=0.96$ for D. filix-mas $\left.\left(20-40{ }^{\circ} \mathrm{C}\right)\right)$. 


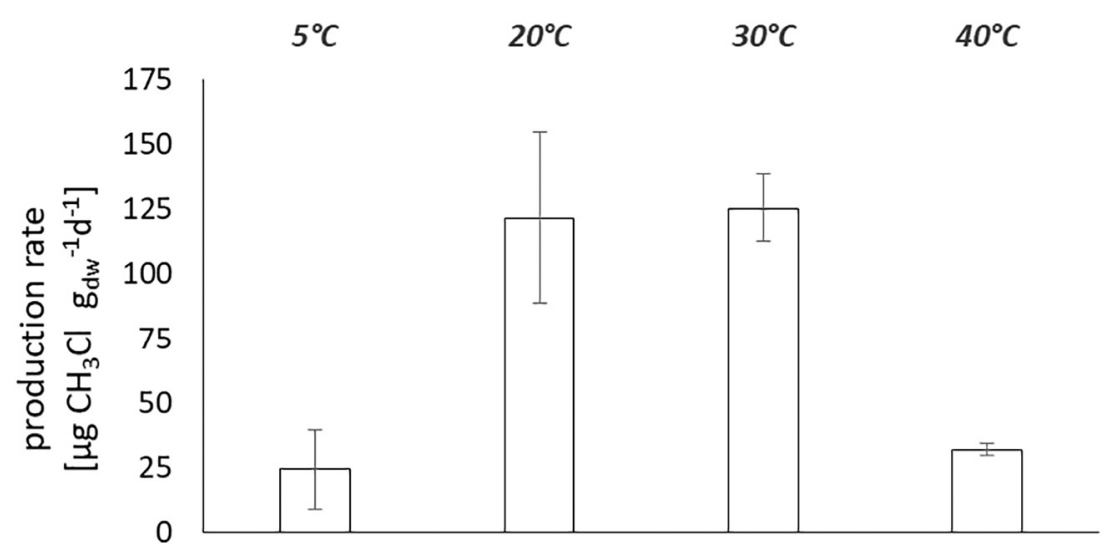

Fig. 3. Temperature dependence of chloromethane emission rates in 0 . regalis. Error bars indicate standard deviation of the mean of three independent experiments.

from the SAM methyl pool with similar $\delta^{2} \mathrm{H}$ value which is reflected by our measurement of the methoxyl groups $(-259 \pm 0.2 \%)$. Thus, assuming that $\mathrm{CH}_{3} \mathrm{Cl}\left(\delta^{2} \mathrm{H}\right.$ value of $-202 \pm 10 \%$ ) released by 0 . regalis is catalyzed by the reaction with SAM then the chloride ion methyltransferase must exhibit a rather small kinetic isotope effect. Moreover, the stable hydrogen fractionation $\left(\Delta=\delta^{2} \mathrm{H}_{\mathrm{CH}_{3} \mathrm{Cl}}-\delta^{2} \mathrm{H}_{\mathrm{HOCH}_{3}}\right)$ during biotic $\mathrm{CH}_{3} \mathrm{Cl}$ production from 0 . regalis of around $50 \%$ is similar to the stable hydrogen fractionation of abiotic $\mathrm{CH}_{3} \mathrm{Cl}$ production from methoxyl groups (1 to 50\%) (Greule et al., 2012).

\subsection{Degradation of chloromethane and its stable isotopic signature}

Chloromethane degradation rates of $C$. cooperi were lowest at $5{ }^{\circ} \mathrm{C}$ with a mean value of $0.30 \pm 0.03 \mu \mathrm{g} \mathrm{g}_{\mathrm{dw}}^{-1} \mathrm{day}^{-1}$ (Fig. 4A) and increased drastically up to $5.8 \pm 1.3 \mu \mathrm{g} \mathrm{g}_{\mathrm{dw}}^{-1} \mathrm{day}^{-1}$ with increasing temperature. A 10 -fold increase of spiked $\mathrm{CH}_{3} \mathrm{Cl}$ mixing ratio resulted only in 3-fold higher degradation rates (Fig. 4A), indicating biotic processes that follow typical Michaelis-Menten-kinetics of enzymatic reactions. During degradation experiments at $20^{\circ} \mathrm{C}$ and $30^{\circ} \mathrm{C}$ as well as increasing supplementation of $\mathrm{CH}_{3} \mathrm{Cl}$ almost no isotope effect was observed for hydrogen as indicated by the stable hydrogen enrichment factor $\varepsilon_{\mathrm{H}}$ with a mean value of $-8 \pm 19 \%$ o (Fig. 4B). The stable hydrogen isotope fractionation is slightly smaller as observed for $\mathrm{CH}_{3} \mathrm{Cl}$ biodegradation in soils $\left(\varepsilon_{\mathrm{H}}-50 \pm 19 \%\right.$, Jaeger et al., 2018), but is in a similar range as it was reported by Nadalig et al. (2014) for $\mathrm{CH}_{3} \mathrm{Cl}$ degradation by Leisingera methylohalidivorans $\mathrm{MB} 2$, a strain able to degrade $\mathrm{CH}_{3} \mathrm{Cl}$ by an unknown dehalogenase. In contrast during incubations at $5{ }^{\circ} \mathrm{C}$, the remaining $\mathrm{CH}_{3} \mathrm{Cl}$ was considerably more enriched in ${ }^{2} \mathrm{H}\left(\varepsilon_{\mathrm{H}}:-142 \pm\right.$ $19 \%$ ), potentially indicating a different process of $\mathrm{CH}_{3} \mathrm{Cl}$ dissipation at much lower ambient temperatures. However, due to the low degradation rates (one to two orders of magnitude lower compared to higher ambient temperatures), we do not consider the results at $5{ }^{\circ} \mathrm{C}$ to be of environmental relevance. Furthermore, considerable enrichment was measured for stable carbon isotopes, with a mean $\varepsilon_{\mathrm{C}}$ of $-43 \pm 12 \%$. This is in the reported $\varepsilon_{\mathrm{C}}$ range for $\mathrm{CH}_{3} \mathrm{Cl}$ degrading bacterial strains (Nadalig et al., 2013) and at the lower end of the $\varepsilon_{\mathrm{C}}$ range for $\mathrm{CH}_{3} \mathrm{Cl}$ removal in soils (Jaeger et al., 2018) ( -38 to $-11 \%$ o). Both hydrogen and stable carbon isotope fractionation were unaffected by temperature at $20^{\circ} \mathrm{C}$ and $30^{\circ} \mathrm{C}$ and the amount of added $\mathrm{CH}_{3} \mathrm{Cl}$ (Fig. 4C). Increased carbon isotope fractionation compared to hydrogen isotope fractionation seems to be the result of the primary isotope effect in cleavage of the carbon-halogen bond during $\mathrm{CH}_{3} \mathrm{Cl}$ dehalogenation, as suggested by Elsner et al. (2005).

\subsection{Composition and diversity of phyllosphere bacterial communities}

The 3 ferns showed clearly different $\mathrm{CH}_{3} \mathrm{Cl}$ formation and consumption patterns. Since the phyllosphere microbiota interacts with volatile organic compounds and atmospheric trace gases (Bringel and Couée, 2015; Farhan ul Haque et al., 2017), we investigated fern leafassociated bacterial diversity further. A total of 30,746 distinct prokaryotic OTUs were detected in the samples investigated. Sequences were assigned to 29 bacterial distinct phyla, 143 families and 314 genera.

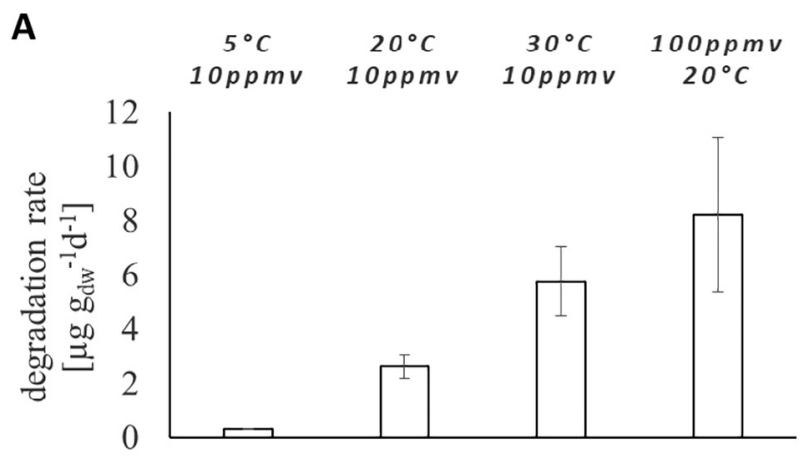

B

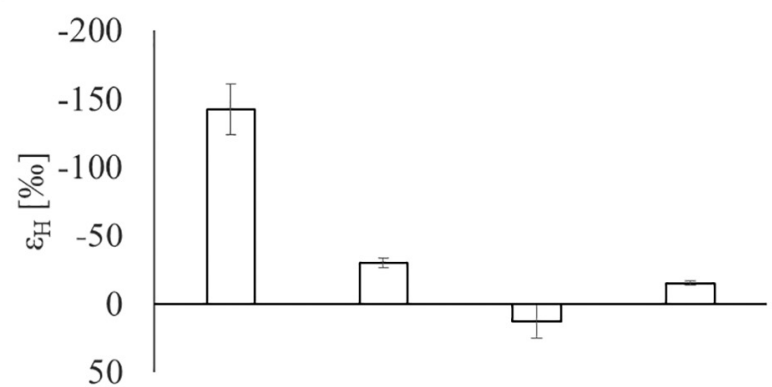

C

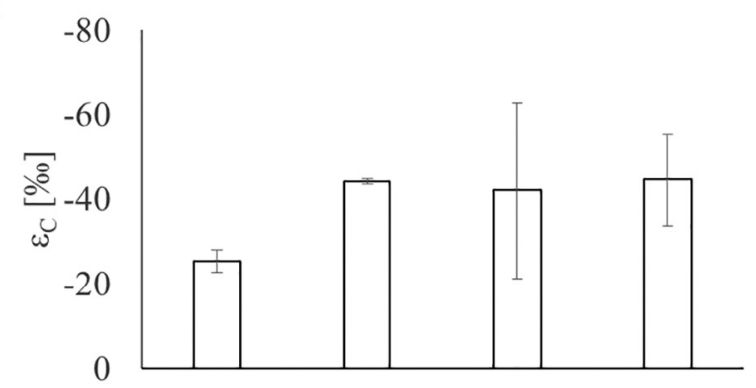

Fig. 4. Net $\mathrm{CH}_{3} \mathrm{Cl}$ degradation rates (A) and stable hydrogen (B) and carbon (C) isotope enrichment factors $\left(\varepsilon_{\mathrm{H}}, \varepsilon_{\mathrm{C}}\right)$ for $\mathrm{C}$. cooperi. Values were determined at $5{ }^{\circ} \mathrm{C}, 20^{\circ} \mathrm{C}$ and $30^{\circ} \mathrm{C}$ after spiking with $10 \mathrm{ppmv} \mathrm{CH}_{3} \mathrm{Cl}$ and at $20^{\circ} \mathrm{C}$ spiked with 100 ppmv $\mathrm{CH}_{3} \mathrm{Cl}$. Error bars indicate standard deviation of the mean of three independent experiments. Please note that leave material of Cyathea cooperi collected for incubation experiments was different to experiments presented in Fig. 2. 
Gammaproteobacteria was by far the predominant phylum in the 3 fern phyllospheres (85.4\% of total reads) (Fig. SM1). Although uncommon (Bringel and Couée, 2015), similar cases of dominance of Gammaproteobacteria in plant phyllosphere communities have been reported (Ren et al., 2014). Notably, at least $53 \%$ of OTUs belonged to the Pseudomonadaceae family (56.5\% of total reads) (Fig. SM2). The genus Pseudomonas alone represented 53.9\% of total reads and at least half of OTUs at the genus level in the investigated ferns (Fig. SM3). Other abundant OTUs were affiliated to Actinobacteria, Alphaproteobacteria and Betaproteobacteria, representing 6, 3.3 and $2.9 \%$ of the total reads, respectively (Fig. SM1). No significant difference was observed in the proportion of these taxa among phyllosphere types (ANOVA; p-value > 0.05) (data not shown). Within the phylum Proteobacteria, four dominant Enterobacteriaceae (Enterobacteriaceae_unclassified, Buttiauxella, Erwinia and Pantoea) were found, with higher abundance in the C. cooperi (55.4\%), D. filixmas $(14.9 \%)$ than in 0 . regalis (11.3\%) (Fig. SM3).

Community richness indices were calculated on datasets rarefied to similar sequence number averaging 225, 215 and 239 OTUs respectively for the C. cooperi, D. filix-mas and $O$. regalis phyllospheres, but no significant difference between them was found (ANOVA; p-value $>0.05$ ) (Table SM2).

\subsection{Occurrence of previously characterized chloromethane-degrading taxa and cmuA in fern leaf bacterial communities}

We investigated whether the microbiota associated with the three fern samples contributes to $\mathrm{CH}_{3} \mathrm{Cl}$ degradation. To do so, we searched for the presence of taxa previously assigned to bacterial $\mathrm{CH}_{3} \mathrm{Cl}$ degraders, and for the presence of the signature gene $\mathrm{cmuA}$. This gene found in contrasting environments is essential for the only known pathway for $\mathrm{CH}_{3} \mathrm{Cl}$ degradation (McAnulla et al., 2001a; Nadalig et al., 2011; Schäfer et al., 2005). Of the 7 genera that have been previously described to have chloromethane-degrading members (Nadalig et al., 2013), within the bacterial taxa identified in the fern samples, only three were detected in this study: i) Pseudomonas was the most abundant genus in the three fern leaves; ii) Methylobacterium was detected in 30 out of 33 samples and averaged $0.17 \%, 0.06 \%$ and $0.89 \%$ respectively for the $C$. cooperi, $D$. filix-mas and 0 . regalis phyllosphere; and iii) Hyphomicrobium was representing around $0.001 \%$ of the total relative abundance in a single Dryopteris sample. In these genera, $\mathrm{cmu}$ genes are rare and have only been found in a few $\mathrm{CH}_{3} \mathrm{Cl}$-degrading isolates (Freedman et al., 2004; Doronina et al., 1996; McDonald et al., 2001; Nadalig et al., 2011). When we investigated the occurrence of $c m u A$ in the studied fern leaf bacterial communities, we were not able to detect cmuA using either a direct endpoint PCR amplification (detection limit of $200 \mathrm{cmuA}$ copies per ng DNA; data not shown) nor a highly sensitive hybridization capture method (Gasc et al., 2016; Denonfoux et al., 2013) for the detection and recovery of rare sequences, with a detection limit of $0.00006 \%$ (sequencing depth of 9,3 million reads) (Gasc and Peyret, 2018). The hybridization-capture-gene sequencing approach was tested for $c m u A$ with DNA extracted from the microbial communities of leaves of the fern $\mathrm{C}$. cooperi displaying the highest $\mathrm{CH}_{3} \mathrm{Cl}$ degrading abilities, but despite the sensitivity of the method no $\mathrm{cmuA}$ sequences were retrieved (data not shown). Altogether, the lack of $c m u A$ detection suggests that the $\mathrm{cmu}$ pathway is not driving $\mathrm{CH}_{3} \mathrm{Cl}$ bacterial consumption in the phyllosphere of $C$. cooperi. Consistently, no $\mathrm{cmu}$ pathway gene or protein sequence has been previously detected by metagenomics and metaproteomics investigations of environmental foliar samples (Delmotte et al., 2009; Knief et al., 2012). Also, $<0.1 \%$ of bacteria on leaf surfaces carried the cmuA gene (Nadalig et al., 2011). Besides the very low abundance of $c m u A$ in the tested fern plants, and possibly in other environments, unknown cmuA-independent $\mathrm{CH}_{3} \mathrm{Cl}$ degrading pathways may be involved in microbial $\mathrm{CH}_{3} \mathrm{Cl}$ consumption as previously suggested (Nadalig et al., 2014).
3.6. Influence of temperature, $\mathrm{CH}_{3} \mathrm{Cl}$ production and degradation parameters on bacterial fern leaf communities

A PCA analysis was used to correlate bacterial community composition with the variations in $\mathrm{CH}_{3} \mathrm{Cl}$ production and consumption in the different fern samples. Analyzed parameters were $\mathrm{CH}_{3} \mathrm{Cl}$ added, temperature, measured $\mathrm{CH}_{3} \mathrm{Cl}$ production rate, measured $\mathrm{CH}_{3} \mathrm{Cl}$ degradation rate and isotopic enrichment factors $\left(\varepsilon_{\mathrm{H}}[\%], \varepsilon_{\mathrm{C}}[\%]\right)$ and the biological community describers (diversity and richness indices). There was no discrimination of the samples following these variables (Fig. 5A), indicating no relationship between microbial community composition and the incubation conditions, chloromethane biodegradation and isotope fractionation (Fig. 5B).

\section{Conclusion}

Ferns investigated in this study displayed either $\mathrm{CH}_{3} \mathrm{Cl}$ strong degradation (Cyathea cooperi and Dryopteris filix-mas) or production (Osmunda regalis). Table 1 summarizes $\mathrm{CH}_{3} \mathrm{Cl}$ flux variations observed between plant families (Osmunda versus Dryopteris), plants of the same species (Cyathea), and individual plants (Yokouchi et al., 2002; Saito and Yokouchi, 2006; Yokouchi et al., 2007, this work). These variations may be the result of complex interactions between genetic, physiological and environmental factors. Factors that may impact directly or indirectly $\mathrm{CH}_{3} \mathrm{Cl}$ biogenic emission rates include: i) the planthalogenating enzyme such as halide/thiocyanate methyl transferase (HTMT) for which a single residue substitution impairs its reactivity with $\mathrm{Cl}^{-}$(Schmidberger et al., 2010); ii) the plant-halogenating enzyme activity (Yokouchi et al., 2002; Itoh et al., 2009) and its speculated reverse dehalogenating reaction (Jeffers et al., 1998); iii) the HTMT expression that can be modulated by glucosinolate metabolism (Nagatoshi and Nakamura 2009), plant development and exposure to pesticides (Bringel and Couée, 2018); iv) the plant metabolic state when stress modifies the substrate SAM methyl donor content (discussed in Saito and Yokouchi, 2006); v) the plant ion content of the substrate methyl acceptor halide $\left(\mathrm{Cl}^{-}, \mathrm{Br}^{-}, \mathrm{I}^{-}\right)$and pseudohalide (NCS $^{-}$) ions (Itoh et al., 2009; Toda and Itoh, 2011; Attieh et al., 2000; Rhew et al., 2003; Blei et al., 2010); vi) the leaf structure and stomatal openness (Niinemets et al., 2004); and finally, vii) the most recently discovered factor, the phyllosphere microbiota (Farhan ul Haque et al., 2017). In this study, no differences in phyllospheric bacterial communities were detected that could account for differences in $\mathrm{CH}_{3} \mathrm{Cl}$ consumption. Nonetheless, the stable carbon isotope enrichment factor of remaining $\mathrm{CH}_{3} \mathrm{Cl}$ was $-39 \pm 13 \%$ o and corresponds to previous results obtained with Methylobacterium extorquens CM4 and Hyphomicrobium sp. MC1 (Nadalig et al., 2013) featuring the $\mathrm{cmu}$ pathway for $\mathrm{CH}_{3} \mathrm{Cl}$ degradation. Indeed, DNA evidence using very sensitive methods strongly suggests that $\mathrm{cmuA}$ is most likely not involved in the observed degradation of $\mathrm{CH}_{3} \mathrm{Cl}$. On the other hand, the stable isotope enrichment observed for hydrogen $(-8 \pm 19 \%$ ) is different than that previously published for $\mathrm{cmu}$ pathway $\mathrm{CH}_{3} \mathrm{Cl}$ degrading strains (Nadalig et al., 2013). This suggests that biodegradation pathways other than $\mathrm{cmu}$ might be involved in the investigated ferns. Uncharacterized $\mathrm{CH}_{3} \mathrm{Cl}$ degradation pathways could be assayed by molecular techniques such as stable isotope probing coupled with metagenomics and metatranscriptomics (Jameson et al., 2016). Despite the technical difficulties involved, we recommend that future studies investigate $\mathrm{CH}_{3} \mathrm{Cl}$ biodegradation at atmospheric levels ( $600 \mathrm{pptv})$, both in the laboratory and in the field, to quantify the microbial $\mathrm{CH}_{3} \mathrm{Cl}$ sink in plants under environmentally relevant conditions.

\section{Acknowledgements}

The CHLOROFILTER project (DFG KE 884/10-1, DFG KO 2912/10-1, ANR-14-CE35-0005-01) was funded by the German Research Foundation (DFG) and The French National Research Agency (ANR). 

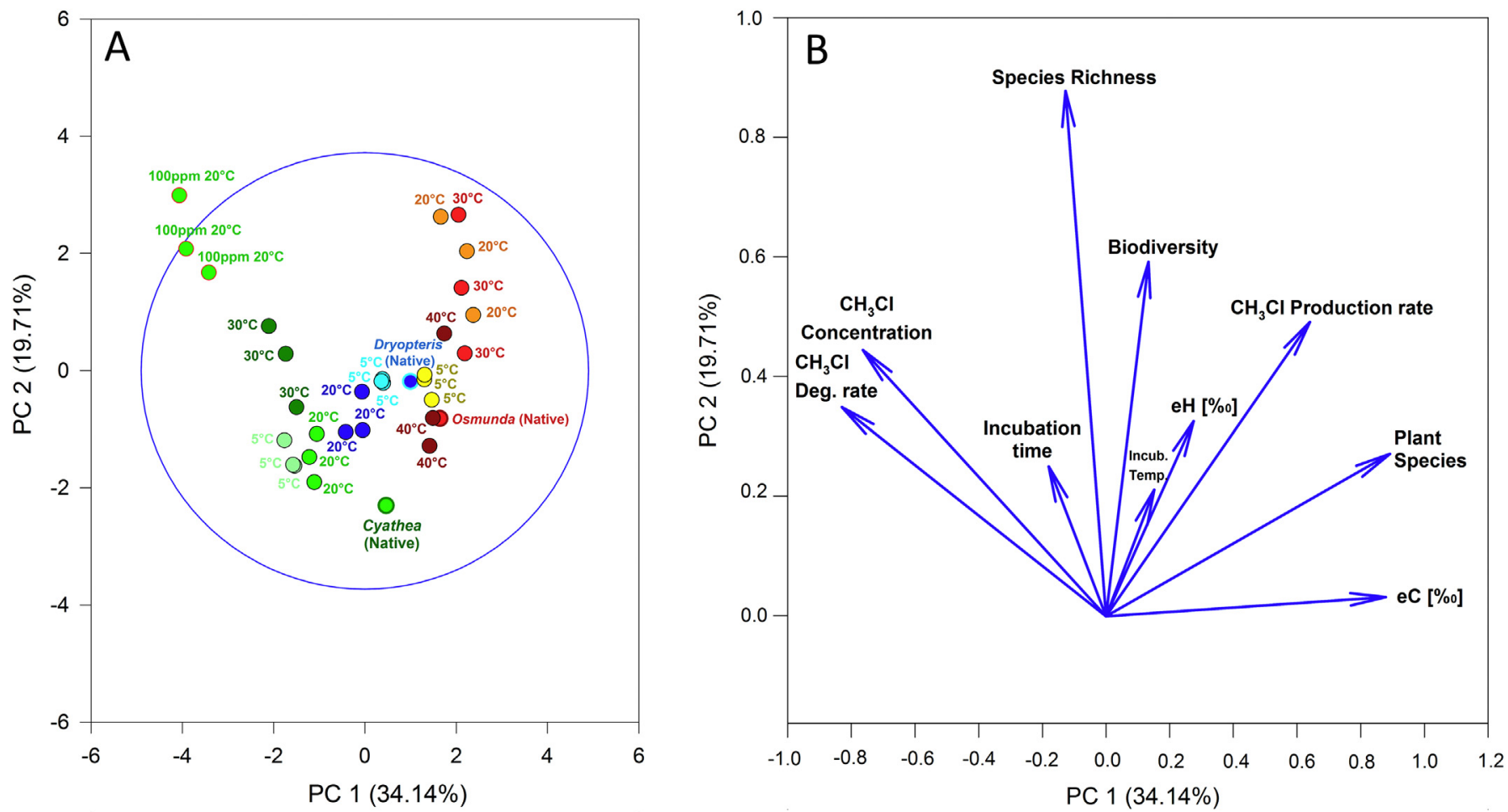

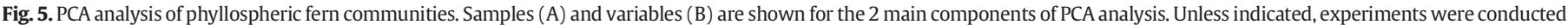

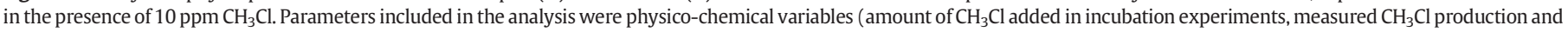
degradation rates, temperature of incubation, and isotopic enrichments $\varepsilon \mathrm{H}[\%], \varepsilon \mathrm{C}[\%]$ ), fern type, and the biological community descriptors (diversity and richness indices).

Furthermore, we thank the Botanical Garden of Heidelberg University for providing fern samples.

\section{Appendix A. Supplementary data}

Supplementary data to this article can be found online at https://doi. org/10.1016/j.scitotenv.2018.03.316.

\section{References}

Ababda-Nkpwatt, D., Müsch, M., Tschiersch, J., Boettner, M., Schwab, W., 2006. Molecular interaction between Methylobacterium extorquens and seedlings: growth promotion, methanol consumption, and localization of the methanol emission site. J. Exp. Bot. 57 (15), 4025-4032.

Andrews, S., 2010. FastQC: A Quality Control Tool for High Throughput Sequence Data. Attieh, J., Sparace, S.A., Saini, H.S., 2000. Purification and properties of multiple isoforms of a novel thiol methyltransferase involved in the production of volatile sulfur compounds from Brassica oleracea. Arch. Biochem. Biophys. 380, 257-266.

Bankevich, A., Nurk, S., Antipov, D., Gurevich, A.A., Dvorkin, M., Kulikov, A.S., Lesin, V.M., Nikolenko, S.I., Pham, S., Prjibelski, A.D., Pyshkin, A.V., Sirotkin, A.V., Vyahhi, N. Tesler, G., Alekseyev, M.A., Pevzner, P.A., 2012. SPAdes: a new genome assembly algorithm and its applications to single-cell sequencing. J. Comput. Biol. 19, 455-477.

Blei, E., Hardacre, C.J., Mills, G.P., Heal, K.V., Heal, M.R., 2010. Identification and quantification of methyl halide sources in a lowland tropical rainforest. Atmos. Environ. 44 1005-1010.

Bringel, F., Couée, I., 2015. Pivotal roles of phyllosphere microorganisms at the interface between plant functioning and atmospheric trace gas dynamics. Front. Microbiol. 6 , 486.

Bringel, F., Couée, I., 2018. Plant-pesticide interactions and the global chloromethane budget. Trends Plant Sci. 23 (2), 95-99.

Bulgarelli, D., Garrido-Oter, R., Münch, P.C., Aaron, W., Dröge, J., Pan, Y., McHardy, A.C. Schulze-Lefert, P., 2015. Structure and function of the bacterial root microbiota in wild and domesticated barley. Cell Host Microbe 17 (3), 392-403.

Carpenter, L.J., Reimann, S., 2014. Scientific Assessment of Ozone Depletion: 2014, Global ozone research and monitoring project - Report No. 55. World Meteorological Organization, Geneva, Switzerland.

Chaignaud, P., Maucourt, B., Weiman, M., Alberti, A., Kolb, S., Cruveiller, S., Vuilleumier, S. Bringel, F., 2017. Genomic and transcriptomic analysis of growth-supporting dehalogenation of chlorinated methanes in Methylobacterium. Front. Microbiol. 8, 1600.
Delmotte, N., Knief, C., Chaffron, S., Innerebner, G., Roschitzki, B., Schlapbach, R., von Mering, C., Vorholt, J.A., 2009. Community proteogenomics reveals insights into the physiology of phyllosphere bacteria. Proc. Natl. Acad. Sci. U. S. A. 106 (38), 16428-16433.

Denonfoux, J., Parisot, N., Dugat-Bony, E., Biderre-Petit, C., Boucher, D., Morgavi, D.P., Le Paslier, D., Peyretaillade, E., Peyret, P., 2013. Gene capture coupled to highthroughput sequencing as a strategy for targeted metagenome exploration. DNA Res. 20 (2), 185-196.

Dimmer, C.H., Simmonds, P.G., Nickless, G., Bassford, M.R., 2001. Biogenic fluxes of halomethanes from Irish peatland ecosystems. Atmos. Environ. 35, 321-330.

Doronina, N.V Sokolov, A.P. Trotsenko, Y.A, 1996. Isolation and initial characterization of aerobic chloromethane-utilizing bacteria. FEMS Microbiol. Lett. 42, 179-183.

Edgar, R.C., Haas, B.J., Clemente, J.C., Quince, C., Knight, R., 2011. UCHIME improves sensitivity and speed of chimera detection. Bioinformatics 27, 2194-2200.

Elsner, M., 2010. Stable isotope fractionation to investigate natural transformation mechanisms of organic contaminants: principles, prospects and limitations. J. Environ. Monit. 12, 2005-2031.

Elsner, M., Zwank, L., Hunkeler, D., Schwarzenbach, R.P., 2005. A new concept linking observable stable isotope fractionation to transformation pathways of organic pollutants. Environ. Sci. Technol. 39, 6896-6916.

Farhan ul Haque, M., Besaury, L., Nadalig, T., Bringel, F, Mutterer, J., Schaller, $\mathrm{H}$., Vuilleumier, S., 2017. Correlated production and consumption of chloromethane in the Arabidopsis thaliana phyllosphere. Sci. Rep. 7, 17582.

Freedman, D.L., Swamy, M., Bell, N.C. Verce, M.F., 2004. Biodegradation of chloromethane by Pseudomonas aeruginosa strain NB1 under nitrate-reducing and aerobic conditions. Appl. Environ. Microbiol. 70 (8), 4629-4634.

Gasc, C., Peyret, P., 2018. Hybridization capture reveals microbial diversity missed using current profiling methods. Microbiome 6 (1), 61.

Gasc, C., Peyretaillade, E., Peyret, P., 2016. Sequence capture by hybridization to explore modern and ancient genomic diversity in model and nonmodel organisms. Nucleic Acids Res. 44, 4504-4518.

Greule, M., Mosandl, A., Hamilton, J.T.G., Keppler, F., 2008. A rapid and precise method for determination of $\mathrm{D} / \mathrm{H}$ ratios of plant methoxyl groups. Rapid Commun. Mass Spectrom. 22, 3983-3988.

Greule, M., Mosandl, A., Hamilton, J.T.G., Keppler, F., 2009. A simple rapid method to precisely determine $13 \mathrm{C} / 12 \mathrm{C}$ ratios of plant methoxyl groups. Rapid Commun. Mass Spectrom. 23, 1710-1714.

Greule, M., Huber, S.G., Keppler, F., 2012. Stable hydrogen-isotope analysis of methyl chloride emitted from heated halophytic plants. Atmos. Environ. 62, 584-592.

Hamilton, J.T.G., McRoberts, W.C., Keppler, F., Kalin, R.M., Harper, D.B., 2003. Chloride methylation by plant pectin: an efficient environmentally significant process. Science 301, 206-209. 
Hammer, Ø., Harper, D.A.T., Ryan, P.D., 2001. PAST-palaeontological statistics, ver. 1.89. Palaeontol. Electron. 4

Harper, D.B., 1985. Halomethane from halide ion - a highly efficient fungal conversion of environmental significance. Nature 315, 55-57.

Harper, D.B., Hamilton, J.T.G., 2003. The global cycles of the naturally-occurring monohalomethanes. In: Gribble, G.W. (Ed.), The Handbook of Environmental Chemistry Vol. 3/P, Natural Production of Organohalogen Compounds, pp. 17-41.

Harper, D.B., Hamilton, J.T.G., Ducrocq, V., Kennedy, J.T., Downey, A., Kalin, R.M., 2003. The distinctive isotopic signature of plant-derived chloromethane: possible application in constraining the atmospheric chloromethane budget. Chemosphere 52, 433-436.

Hartmans, S., Schmuckle, A., Cook, A.M., Leisinger, T., 1986. Methyl chloride: naturally occurring toxicant and C1 growth substrate. J. Gen. Microbiol. 132, 1139-1142.

Itoh, N., Toda, H., Matsuda, M., Negishi, T., Taniguchi, T., Ohsawa, N., 2009. Involvement of S-adenosylmethionine-dependent halide/thiol methyltransferase (HTMT) in methyl halide emissions from agricultural plants: isolation and characterization of an HTMT-coding gene from Raphanus sativus (daikon radish). BMC Plant Biol. 9, 116.

Jaeger, N., Besaury, L., Kröber, E., Delort, A.M., Greule, M., Lenhart, K., Nadalig, T., Vuilleumier, S., Amato, P., Kolb, S., Bringel, F., Keppler, F., 2018. Chloromethane degradation in soils: A combined microbial and two-dimensional stable isotope approach. J. Environ. Qual. 47 (2), 254-262.

Jameson, E., Taubert, M., Coyotzi, S., Chen, Y., Eyice, Ö., Schäfer, H., Murrell, J.C., Neufeld, J.D., Dumont, M.G., 2016. DNA-, RNA-, and protein-based stable-isotope probing for high-throughput biomarker analysis of active microorganisms. Metagenomics. Springer New York, pp. 57-74 (ISBN 978-1-4939-6689-9).

Jeffers, P.M., Wolfe, N.L., Nzengunget, V., 1998. Green plants: a terrestrial sink for atmospheric CH3Br. Geophys. Res. Lett. 25, 43-46.

Keene, W.C., Khalil, M.A.K., Erickson, D.J., et al., 1999. Composite global emissions of reactive chlorine from anthropogenic and natural sources: reactive chlorine emissions inventory. J. Geophys. Res. Atmos. 104, 8429-8440.

Keppler, F., Eiden, R., Niedan, V., Pracht, J., Scholer, H.F., 2000. Halocarbons produced by natural oxidation processes during degradation of organic matter. Nature 403, 298-301.

Keppler, F., Kalin, R., Harper, D., McRoberts, W.C., Hamilton, J.T.G., 2004. Carbon isotope anomaly in the major plant $\mathrm{C} 1$ pool and its global biogeochemical implications. Biogeosciences 1, 393-412.

Keppler, F., Harper, D.B., Rockmann, T., Moore, R.M., Hamilton, J.T.G., 2005. New insight into the atmospheric chloromethane budget gained using stable carbon isotope ratios. Atmos. Chem. Phys. 5, 2403-2411.

Knief, C., Delmotte, N., Chaffron, S., Stark, M., Innerebner, G., Wassmann, R., von Mering, C., Vorholt, J.A., 2012. Metaproteogenomic analysis of microbial communities in the phyllosphere and rhizosphere of rice. ISME J. 6 (7), 1378-1390.

Langmead, B., Salzberg, S.L., 2012. Fast gapped-read alignment with Bowtie 2. Nat. Methods 9 (4), 357-359.

Li, S., Park, M.-K., Jo, C.O., Park, S., 2016. Emission estimates of methyl chloride from industrial sources in China based on high frequency atmospheric observations. J. Atmos. Chem. 1-17.

McAnulla, C., Woodall, C.A., McDonald, I.R., Studer, A., Vuilleumier, S., Leisinger, T., Murrell, J.C., 2001a. Chloromethane utilization gene cluster from Hyphomicrobium chloromethanicum strain CM2(T) and development of functional gene probes to detect halomethane-degrading bacteria. Appl. Environ. Microbiol. 67 (1), 307-316.

McAnulla, C., McDonald, I.R., Murrell, J.C., 2001b. Methyl chloride utilising bacteria are ubiquitous in the natural environment. FEMS Microbiol. Lett. 201 (2), 151-155.

McDonald, I.R., Doronina, N.V., Trotsenko, Y.A., McAnulla, C., Murrell, J.C., 2001. Hyphomicrobium chloromethanicum sp. nov. and Methylobacterium chloromethanicum sp. nov., chloromethane-utilizing bacteria isolated from a polluted environment. Int. J. Syst. Evol. Microbiol. 51, 119-122.

McRoberts, W.C., Keppler, F., Harper, D.B., Hamilton, J.T.G., 2015. Seasonal changes in chlorine and methoxyl content of leaves of deciduous trees and their impact on release of chloromethane and methanol at elevated temperatures. Environ. Chem. 12, 426-437.

Miller, L., Kalin, R.M., McCauley, S.E., Hamilton, J.T.G., Harper, D.B., Millet, D.B., Oremland, R.S., Goldstein, A.H., 2001. Large carbon isotope fractionation associated with oxidation of methyl halides by methylotrophic bacteria. Proc. Natl. Acad. Sci. U. S. A. 98, 5833-5837.

Miller, L., Warner, K.L., Baesman, S.M., Oremland, R.S., McDonald, I.R., Radajewski, S., Murrell, J.C., 2004. Degradation of methyl bromide and methyl chloride in soil microcosms: use of stable $\mathrm{C}$ isotope fractionation and stable isotope probing to identify reactions and the responsible microorganisms. Geochim. Cosmochim. Acta 68, 3271-3283.

Moore, R.M., Groszko, W., Niven, S.J., 1996. Ocean-atmosphere exchange of methyl chloride: results from NW Atlantic and Pacific Ocean studies. J. Geophys. Res. Oceans 101, 28529-28538.

Nadalig, T., Farhan Ul Haque, M., Roselli, M., Schaller, H., Bringel, F., Vuilleumier, S., 2011. Detection and isolation of chloromethane-degrading bacteria from the Arabidopsis thaliana phyllosphere, and characterization of chloromethane utilisation genes. FEMS Microbiol. Ecol. 77, 438-448.

Nadalig, T., Greule, M., Bringel, F., Vuilleumier, S., Keppler, F., 2013. Hydrogen and carbon isotope fractionation during degradation of chloromethane by methylotrophic bacteria. MicrobiologyOpen 2 (6), 893-900.

Nadalig, T., Greule, M., Bringel, F., Keppler, F., Vuilleumier, S., 2014. Probing the diversity of chloromethane-degrading bacteria by comparative genomics and isotopic fractionation. Front. Microbiol. 5, 523.
Nagatoshi, Y., Nakamura, T., 2009. Arabidopsis HARMLESS TO OZONE LAYER protein methylates a glucosinolate breakdown product and functions in resistance to Pseudomonas syringae pv. maculicola. J. Biol. Chem. 284, 19301-19309.

Ni, X., Hager, L.P., 1999. Expression of Batis maritima methyl chloride transferase in Escherichia coli. Proc. Natl. Acad. Sci. 96, 3611-3615.

Niinemets, U., Loreto, F., Reichstein, M., 2004. Physiological and physicochemical controls on foliar volatile organic compound emissions. Trends Plant Sci. 9, 180-186.

Parisot, N., Denonfoux, J., Dugat-Bony, E., Peyret, P., Peyretaillade, E., 2012. KASpOD-a web service for highly specific and explorative oligonucleotide design. Bioinformatics 28, 3161-3162.

Quast, C., Pruesse, E., Yilmaz, P., Gerken, J., Schweer, T., Yarza, P., Peplies, J., Glöckner, F.O. 2012. The SILVA ribosomal RNA gene database project: improved data processing and web-based tools. Nucleic Acids Res. 41, 590-596.

Redeker, K.R., Wang, N.-Y., Low, J.C., McMillan, A., Tyler, S.C., Cicerone, R.J., 2000. Emissions of methyl halides and methane from rice paddies. Science 290, 966-969.

Ren, G., Zhang, H., Lin, X., Zhu, J., Jia, Z., 2014. Response of phyllosphere bacterial communities to elevated $\mathrm{CO}_{2}$ during rice growing season. Appl. Microbiol. Biotechnol. 98, 9459-9471.

Rhew, R.C., 2011. Sources and sinks of methyl bromide and methyl chloride in the tallgrass prairie: applying a stable isotope tracer technique over highly variable gross fluxes. J. Geophys. Res. 116, G03026.

Rhew, R.C., Abel, T., 2007. Measuring simultaneous production and consumption fluxes of methyl chloride and methyl bromide in annual temperate grasslands. Environ. Sci. Technol. 41, 7837-7843.

Rhew, R.C., Miller, B.R., Weiss, R.F., 2000. Natural methyl bromide and methyl chloride emissions from coastal salt marshes. Nature 403, 292-295.

Rhew, R.C., Ostergaard, L., Saltzman, E.S., Yanofsky, M.F., 2003. Genetic control of methyl halide production in Arabidopsis. Curr. Biol. 13, 1809-1813.

Ribière, C., Beugnot, R., Parisot, N., Gasc, C., Defois, C., Denonfoux, J., Boucher, D., Peyretaillade, E., Peyret, P., 2016. Targeted gene capture by hybridization to illuminate ecosystem functioning. Methods Mol. Biol. 1399, 167-182.

Roselli, S., Nadalig, T., Vuilleumier, S., Bringel, F., 2013. The 380 kb pCMU01 plasmid encodes chloromethane utilization genes and redundant genes for vitamin $\mathrm{B}_{12}$ - and tetrahydrofolate-dependent chloromethane metabolism in Methylobacterium extorquens CM4: a proteomic and bioinformatics study. PLoS One 8 (4), e56598.

Sailaukhanuly, Y., Sárossy, Z., Carlsen, L., Egsgaard, H., 2014. Mechanistic aspects of the nucleophilic substitution of pectin. On the formation of chloromethane. Chemosphere 111, 575-579.

Saito, T., Yokouchi, Y., 2006. Diurnal variation in methyl halide emission rates from tropical ferns. Atmos. Environ. 40, 2806-2811.

Saito, T., Yokouchi, Y., 2008. Stable carbon isotope ratio of methyl chloride emitted from glasshouse-grown tropical plants and its implication for the global methylchloride budget. Geophys. Res. Lett. 35, L08807.

Saito, T., Yokouchi, Y., Phillip, E., Okuda, T., 2013. Bidirectional exchange of methy halides between tropical plants and the atmosphere. Geophys. Res. Lett. 40, 5300-5304.

Schäfer, H., McDonald, I.R., Nightingale, P.D., Murrell, J.C., 2005. Evidence for the presence of a CmuA methyltransferase pathway in novel marine methylhalide-oxidizing bacteria. Environ. Microbiol. 7, 839-852.

Schloss, P.D., Westcott, S.L., Ryabin, T., Hall, J.R., Hartmann, M., Hollister, E.B., Lesniewski, R.A., Oakley, B.B., Parks, D.H., Robinson, C.-J., Sahl, J.W., Stres, B., Thallinger, G.G., Van Horn, D.J., Weber, C.F., 2009. Introducing mothur: open-source, platformindependent, community-supported software for describing and comparing microbial communities. Appl. Environ. Microbiol. 75, 7537-7541.

Schmidberger, J.W., James, A.B., Edwards, R., Naismith, J.H., O'Hagan, D., 2010 Halomethane biosynthesis: structure of a SAM-dependent halide methyltransferase from Arabidopsis thaliana. Angew. Chem. Int. Ed. Eng. 49, 3646-3648.

Schmieder, R., Edwards, R., 2011. Quality control and preprocessing of metagenomic datasets. Bioinformatics 27, 863-864.

Studer, A., Vuilleumier, S., Leisinger, T., 1999. Properties of the methylcobalamin: $\mathrm{H}_{4}$ folate methyltransferase involved in chloromethane utilization by Methylobacterium sp. strain CM4. Eur. J. Biochem. 264, 242-249.

Studer, A., Stupperich, E., Vuilleumier, S., Leisinger, T., 2001. Chloromethane: tetrahydrofolate methyl transfer by two proteins from Methylobacterium chloromethanicum strain CM4. Eur. J. Biochem. 268, 2931-2938.

Teh, Y.A., Rhew, R.C., Atwood, A., Abel, T., 2008. Water, temperature, and vegetation regulation of methyl chloride and methyl bromide fluxes from a shortgrass steppe ecosystem. Glob. Chang. Biol. 14, 77-91.

Toda, H., Itoh, N., 2011. Isolation and characterization of a gene encoding a S-adenosyl-Lmethionine-dependent halide/thiol methyltransferase (HTMT) from the marine diatom Phaeodactylum tricornutum: biogenic mechanism of $\mathrm{CH}(3) \mathrm{I}$ emissions in oceans. Phytochemistry 72, 337-343.

Traunecker, J., Preuss, A., Diekert, G., 1991. Isolation and characterization of a methyl chloride utilizing, strictly anaerobic bacterium. Arch. Microbiol. 156, 416-421.

Valtanen, A., Solloch, S., Hartikainen, H., Michaelis, W., 2009. Emissions of volatile halogenated compounds from a meadow in a coastal area of the Baltic sea. Boreal Environ. Res. 14, 915-931.

Vannelli, T., Messmer, M., Studer, A., et al., 1999. A corrinoid-dependent catabolic pathway for growth of a Methylobacterium strain with chloromethane. Proc. Natl. Acad. Sci. USA 96, 4615-4620.

Weilacher, T., Gleixner, G., Schmidt, H.L., 1996. Carbon isotope pattern in purine alkaloids a key to isotope discriminations in C1 compounds. Phytochemistry 41 1073-1077.

Wishkerman, A., Gebhardt, S., McRoberts, C.W., Hamilton, J.T.G., Williams, J., Keppler, F., 2008. Abiotic methyl bromide formation from vegetation, and its strong dependence on temperature. Environ. Sci. Technol. 42, 6837-6842. 
Wuosmaa, A.M., Hager, L.P., 1990. Methyl chloride transferase: a carbocation route for biosynthesis of halometabolites. Science 249, 160-162.

Xiao, X., Prinn, R.G., Fraser, R.J., 2010. Optimal estimation of the surface fluxes of methyl chloride using a 3D global chemical transport model. Atmos. Chem. Phys. 10, 5515-5533.

Yokouchi, Y., Ikeda, M., Inuzuka, Y., Yukawa, T., 2002. Strong emission of methyl chloride from tropical plants. Nature 416, 163-165.
Yokouchi, Y., Saito, T., Ishigaki, C., Aramoto, M., 2007. Identification of methyl chlorideemitting plants and atmospheric measurements on a subtropical island. Chemosphere 69, 549-553.

Yokouchi, Y., Takenaka, A., Miyazaki, Y., Kawamura, K., Hiura, T., 2015. Emission of methyl chloride from a fern growing in subtropical, temperate and cool-temperate climate zones. J. Geophys. Res. Biogeosci. 120 (6), 1142-1149. 